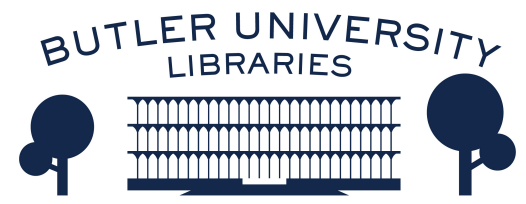

Journal of Hindu-Christian Studies

Volume 32 Discussion of Nathaniel Roberts, To

Be Cared For: The Power of Conversion and

Foreignness of Belonging to An Indian Slum.

Article 19

2019

\title{
Book Review: Heathen, Hindoo, Hindu: American Representations of India, 1721-1893
}

Jeffrey M. Brackett

Ball State University

Follow this and additional works at: https://digitalcommons.butler.edu/jhcs

\section{Recommended Citation}

Brackett, Jeffrey M. (2019) "Book Review: Heathen, Hindoo, Hindu: American Representations of India, 1721-1893," Journal of Hindu-Christian Studies: Vol. 32, Article 19.

Available at: https://doi.org/10.7825/2164-6279.1745

The Journal of Hindu-Christian Studies is a publication of the Society for Hindu-Christian Studies. The digital version is made available by Digital Commons @ Butler University. For questions about the Journal or the Society, please contact cbauman@butler.edu. For more information about Digital Commons @ Butler University, please contact digitalscholarship@butler.edu. 
The most compelling and provocative chapter of the volume is, in my view, the penultimate (Chapter 10), in which Rebecca Samuel Shah and Timothy Samuel Shah provide data on the unusually rational and financially beneficial lifestyle changes adopted by converts to Christianity in a Bangalore slum in order to refute the nationalist narrative that such converts lack the ability to be thoughtful about religious affairs and therefore lack religious agency until lured to Christianity by duplicitous missionaries. Data from their survey of hundreds of female slum residents indicates that Christians (particularly Protestants, and especially converts to Christianity) were far less likely than members of other religious groups to spend on luxury goods, far more likely to spend on functional items (e.g., refrigerators, washing machines), far more likely to negotiate with their bosses for better salaries, and far more likely to talk to authorities in their life (e.g., pastors) about experiences of domestic violence. Conversion therefore contributes to the expression of agency among low-caste slum-dwellers. These data, the authors argue, provide more evidence of the benefits of religious freedom, which in their view is under attack not only from religious nationalists around the world, but also from western secular intellectuals like Elizabeth Shakman Hurd, Winnifred Fallers Sullivan, Saba Mahmood, and others.

While uneven, and only loosely organized around a theme, then, this volume has much to offer. It is accessible and current, and contains essays both complex and more general/introductory. For this reason, surely everyone could find in it at least several chapters of interest and value.

Chad M. Bauman

Butler University

\section{Heathen, Hindoo, Hindu: American Representations of India, 1721- 1893. By Michael J. Altman. New York: Oxford University Press, 2017, vii + 175 pages.}

ALTMAN'S book contributes much to our understanding of how "Hinduism" came to be imagined in America. He dismantles neat narratives, replacing them with a sophisticated analysis of ever-changing fragments that have long intersected in a variety of ways. His keen attention to historical details presents a complex set of developments that disrupt, in particular, notions of Hinduism as a stable category predicated on conceptions of belief and practice.

The author's intended goal is to analyze a variety of terms used to represent Hindus and Hinduism in order to illustrate how these categories were constructed and deployed in America. The goal is neither to show Hinduism to be merely a constructed term nor to argue that Hinduism does not really exist.

Previous studies of Hinduism in America, argues Altman, tended to locate a Hinduism that neatly aligned with a pre-defined "Hinduism" replete with beliefs, practices, and sacred texts. Such studies presented a Hinduism marked by its movement, as though describing a stable object. Not only do these representations miss the wildly varied forms of Hinduism, they fail to mention the representations of Hinduism in American discourse about the so-called Hindoos. That is, 
Altman avers, much can be gained by examining ways that Americans described "Hinduism" (and related terms).

The usual narratives of "Hinduism in America" note the influence of Transcendentalists, Theosophists, Vivekananda, the 1965 immigration laws, and then culminate in studies showing how Hindus became part of pluralistic America (i.e., through building temples, etc.) (xvi). However, argues Altman, "There are serious problems with these accounts of 'Hinduism in America"' (17).

Rather than continuing along the lines of either the constructivist or correspondence definitions of Hinduism, each of which have problems, Altman shifts the line of inquiry away from focusing on establishing origins or "accurate" correspondences between (usually textual) ideals and practice to illustrate a different historical trajectory: "I want to know how Hinduism became conceivable in America... Instead of finding its origin, I want to trace its emergence" (xx). This approach aligns with Will Sweetman's argument that "Hinduism" is a tool for analysis, not an object with ontological status (xx). Further, Altman asks how and where the notion of "Hinduism" was even possible.

Thus, Altman presents his study as a genealogy, with a focus on how representations of religion in India-mainly by white people in the northeastern US-to provide one way of understanding what it means to be "American." By studying, for example, the representations by (mostly) white Protestant Americans of the so-called heathens, Hindoos, and Hindus, one learns more about Protestant debates about the term "religion" itself than religion in India. The malleable terms assume diverse shapes in connection with particular interests: missionaries set on saving the heathens by bringing them the gospel; British Orientalists locating "true Hinduism" in Sanskrit texts, which, of course are juxtaposed to rational Enlightenment thought and thereby proved inferior; and East India Company members profiting from pedaling exotic products from the same Hindoos.

Altman's work will appeal to a broad range of scholars, as his work engages in debates about concepts fundamental to the study of religion, Orientalism, the Other, American history (especially religious history), nationalism, education, and much more. He deftly illustrates how all of these topics are intertwined, and he triangulates each with indepth analysis of events and documents in America, India, and Europe. While many of the topics are familiar to scholars, Altman adds significantly to our understanding of them by utilizing important (yet seemingly obscure) sources (e.g., Hannah Adams's four editions of an encyclopedia, among other works) that add a lot of nuance.

Altman's analysis of categories, terms, classificatory systems and how they develop, influence one another, agree, disagree, converge and diverge (and so on) is impressive. The only quibble this reviewer has with his argument is that Altman selectively (or unfairly) represents the work of Narayanan, Kurien, and Prothero as he lays out the goals of his own work. More nuance and context for their work would have been useful in setting up the original contributions Altman provides. However, this minor point really does not detract from the overall import of Altman's analysis, which, as noted, is a careful, detailed, nuanced, sophisticated genealogical study of key terms, people, events, and historical developments.

Along the way, readers will encounter stories of mariners whose whimsical "collection of curiosities" contributed to an 
imagined Oriental Other; American geography textbooks that added to classificatory systems of race and religion, while promoting the superiority of American culture; and carefully constructed critiques of the typical narratives regarding the roles of Transcendentalism, Thoreau, Emerson, Theosophy, the 1893 World
Parliament of Religions, and much more. There is much to gain from Altman's work, and one hopes it will gain a wide audience.

Jeffrey M. Brackett

Ball State University

\section{Privileged Minorities: Syrian Christianity, Gender, and Minority Rights in Postcolonial India. By Sonja Thomas. Seattle: University of Washington Press, 2018, $\mathrm{x}+210$ pages.}

WHILE there now exist a number of studies of Kerala's Syrian Christians from a variety of different perspectives, Thomas' new investigation provides a fresh and provocative examination of the community using the critical lenses of gender, caste, religion and politics. No doubt, some of the staunch supporters of one of Christianity's oldest traditions will take affront at many of the arguments and claims of the author. However, she has not taken her assignment lightly, providing a rigorous interrogation of the community to which she is personally connected. One may argue and disagree with some of the contentions of the work, as this reviewer does, but one must not dismiss it as unreasonable or unscholarly, and therefore hopelessly biased.

Thomas helpfully locates herself as an insider outsider, growing up in a diasporic Syrian Christian (Syro-Malabar Catholic) community in a rural area of the United States (19). This personal history provides her with a unique scholarly location: as one who speaks the language and understands the culture of her interlocutors, yet as one who has a somewhat different perspective on their community than they generally do. It is, I would argue, this liminal location that provides one of the many fascinating and commendable features of the study, which is that the author critiques a whole range of established scholarship in both South Asian and feminist studies, as she crafts and develops her own arguments and insights into the ways that different segments of the SyroMalabar Catholic community in Travancore, Kerala, have operated to maintain their privilege.

The Introduction of the volume begins by providing a brief demographic and sociological description of the Syrian Christian community in the context of Kerala and of the Indian nation state as a whole. second, it announces the overarching analytical themes that run throughout the work, namely those of gender, caste, class, religion and minority politics. The volume brings together these different vectors of analysis in its examination of Syrian Christians in Kerala (11). Next comes a brief discussion of why scholars have treated Kerala as an exception in their examinations of secularism, and almost completely ignored the issue of education-an issue that the work takes up later. The Introduction ends with an overview of the book's chapters and its research methodology, which employs and engages a number of different academic fields and disciplines. 